\title{
Bullous pemphigoid in infants: characteristics, diagnosis and treatment
}

\author{
Agnes Schwieger-Briel ${ }^{1,5^{*}}$, Cornelia Moellmann ${ }^{1}$, Birgit Mattulat ${ }^{2}$, Franziska Schauer ${ }^{1}$, Dimitra Kiritsi ${ }^{1}$, Enno Schmidt ${ }^{3}$, \\ Cassian Sitaru', Hagen Ott ${ }^{3,4}$ and Johannes S Kern ${ }^{1 *}$
}

\begin{abstract}
Background: Bullous pemphigoid (BP) in infants is a rare but increasingly reported autoimmune blistering skin disease. Autoantibody reactivity is usually poorly characterized. Current guidelines do not address specific aspects of the infantile form of BP. The objectives of this study are to define clinical and diagnostic characteristics of infantile $\mathrm{BP}$ and develop a treatment algorithm.

Methods: Detailed characterization of a current case series of five infants with BP from our departments. Comprehensive analysis of all reported cases (1-12 months) with respect to clinical and laboratory characteristics, treatment and outcome.

Results: In total 81 cases were identified (including our own). The mean age was 4.5 months. Moderately severe and severe disease was seen in $84 \%$ of cases. Involvement of hands and feet was present in all cases.

Immunofluorescence microscopy was comparable with BP in adults. Where analyzed, the NC16A domain of bullous pemphigoid $180 \mathrm{kDa}$ antigen/collagen XVII (BP180) was identified as the major target antigen. BP180 NC16A ELISA values in our cohort were significantly higher than in a control cohort of 28 newly diagnosed adult patients. $50 \%$ of patients were treated with systemic corticosteroids, $20 \%$ with a combination of systemic corticosteroids and dapsone or sulfapyridine and $10 \%$ with topical corticosteroids alone. $14 \%$ of patients needed a combination of multiple immunosuppressants. All but one patient reached remission. Relapses were rare.

Conclusions: Presentation of infantile BP is often severe with blistering of hands and feet present in all cases. Pathogenesis and diagnostic criteria are comparable to adult BP, yet BP180 NC16A ELISA levels seem to be significantly higher in infants. The overall disease outcome is favorable. Based on the results of this study we propose a treatment algorithm for infantile BP.
\end{abstract}

Keywords: Bullous skin disease, Skin blistering, Vaccination

\section{Background}

Bullous pemphigoid (BP, ORPHA703) is an acquired autoimmune disorder presenting with subepidermal blistering, eosinophilia, and severe itch [1-5]. Its incidence is increasing [6,7] and it mostly affects the elderly; it is considered rare in children [8,9]. The first case of BP in a child was described in 1970 based on immunofluorescence diagnosis [10]; the first case of BP in an infant was described in 1977 [11]. Since then, the number of reported pediatric cases has steadily increased, prompting

\footnotetext{
* Correspondence: agnes.schwieger@uniklinik-freiburg.de; johannes.steffen. kern@uniklinik-freiburg.de

${ }^{1}$ Departments of Dermatology and Pediatrics, Medical Center - University of Freiburg, Freiburg, Germany

Full list of author information is available at the end of the article
}

Nemeth et al. to propose diagnostic criteria for childhood BP [12] which included children and adolescents up to 18 years of age. In 2008, Waisbourd-Zinman et al. noticed different clinical presentations depending on the age of affected children [13]. In a literature review, they showed that the majority of cases of childhood BP occurred in small children under the age of 12 months and that these infants presented with a particular clinical picture. All affected infants had acral involvement with or without generalized blistering. The distribution in later childhood was far less uniform and included a subgroup of children with localized genital BP, a presentation not described in infants. These clinical differences led to the distinction of infantile versus childhood BP [13]. 
Diagnostic results in infantile and adult BP are similar, but serological tests were not performed systematically in many of the reported cases [13]. The gold standard for diagnosis is direct immunofluorescence microscopy (DIF). However, little information is available on the interpretation of ELISA levels [14], inflammatory markers or blood cell counts in infants. Further knowledge, especially about the relevance of ELISA levels might help to assess disease severity and thus influence the choice of medication or duration of treatment.

Concerning the treatment of infantile BP, first line treatment usually consists of topical or systemic corticosteroids. However, there are no stringent therapeutic criteria and there has been very little discussion on the different options for second line treatment. Furthermore, in clinical consensus guidelines on treatment of BP, there is very little, if any, information on treatment in infants [15-18].

Here, we report the diagnostic results and disease course of five children with infantile BP in our care and a comprehensive analysis of all cases reported in the literature. Based on these data - and taking into account the published guidelines for adults as well as special circumstances of treating small infants - we propose a first treatment algorithm for infantile BP.

\section{Methods}

\section{Infantile BP cohort and adult BP control cohort}

Five infantile BP patients presented at or were referred to our departments. They were included in this study after we obtained parental informed consent for participation and took blood and skin samples for diagnostic and research purposes. As a control, BP180 NC16A ELISA levels of a cohort of 28 adult BP patients that were newly diagnosed in the same time period were determined after informed consent was provided. All investigations were conducted according to the declaration of Helsinki criteria.

\section{Histopathology, immunofluorescence microscopy, immunoblotting and ELISA}

Hematoxylin eosin staining of formalin fixed, paraffin embedded tissue sections was performed using standard methods. DIF and indirect immunofluorescence microscopy (IIF) were performed as previously described [19-21]. FITC labeled antibodies used for DIF were anti human IgG, IgA, IgM and C3c (Dako, Hamburg, Germany) at a dilution of 1:200, 1:50, 1:50 and 1:500 respectively. For IIF on salt-split skin, patient sera were diluted 1:10, secondary antibodies used were FITC labeled anti human IgG and IgA (Dako, Hamburg, Germany) at a dilution of 1:100 and 1:25 respectively. Immunoblotting of normal human keratinocyte extracts with patient sera at a 1:20 dilution and alkaline phosphatase anti human IgG (Sigma-Aldrich, Taufkirchen, Germany) secondary antibody was performed as previously described [20,21]. ELISA kits for the detection of BP180- and bullous pemphigoid $230 \mathrm{kDa}$ antigen (BP230)-specific antibodies (MBL, Nagoya, Japan) were used according to the manufacturer's protocol with the cut-off at $9 \mathrm{U} / \mathrm{ml}$.

\section{Statistical analysis}

Boxplot descriptive statistics of BP180 NC16A ELISA values were performed using GraphPad Prism software (GraphPad Software, La Jolla, CA).

\section{Literature search}

We searched all retrievable English- and foreign-language medical literature using PubMed, PubMed Central, EMBASE, and Google Scholar databases as well as literature cited in the obtained reports. Relevant information was extracted and reviewed to avoid duplications of reports. We included only infants up to 12 months in our review and excluded cases of neonatal BP.

\section{Results}

\section{Patient cohort/index case}

The clinical and laboratory findings of the five patients in our cohort are presented in Table 1. Patient 1 (index case) showed characteristic infantile BP and was the most severely affected; his treatment proved to be the most challenging. $\mathrm{He}$ is therefore presented in more detail. The previously healthy three-month-old boy of Algerian descent presented with a one-week history of small blisters on hands and feet and urticarial plaques on the trunk. Impetigo had been ruled out at a nearby hospital but no diagnosis had been made. He had received one oral vaccination against Rotavirus one month prior. No other vaccinations had been given. Apart from mild eczema, there was no family history of skin disease. Over the course of one week the lesions increased in number and size. The patient was irritable and not feeding well.

On clinical examination, he had firm blisters and bullae predominantly on the hands and feet, as well as urticarial plaques with an elevated rim and a dusky center. These plaques were predominantly located on the trunk but also present on all other areas of the body (Figure 1A, B). The Nikolsky sign was negative; there were no mucosal lesions.

Blister fluid microscopy demonstrated mainly eosinophil granulocytes; cultures from blister fluid remained sterile. Blood testing, including a full blood count, showed normal values with the exception of a peripheral eosinophilia of $10 \%$. Punch biopsies were performed for histologic and immunofluorescence analyses. Histology showed dermal edema and eosinophil inflammatory infiltrate (not shown). DIF revealed linear staining of IgG (Figure 1E) and complement component C3 (Figure 1F) along the basement membrane zone. IIF microscopy showed circulating IgG autoantibodies binding to the 
Table 1 Clinical and laboratory findings of the patient cohort

\begin{tabular}{|c|c|c|c|c|c|c|c|c|c|}
\hline & $\begin{array}{l}\text { Age (months)/ } \\
\text { Gender }\end{array}$ & $\begin{array}{l}\text { Extent of Disease/ } \\
\text { Hands/Feet (HF) }\end{array}$ & OM & $\begin{array}{l}\text { DIF/IIF/ } \\
\text { Immunoblot }\end{array}$ & ELISA & $\begin{array}{l}\text { WBC (Eos in\%) } \\
\text { Thrombocytes }\end{array}$ & Treatment & $\begin{array}{l}\text { Time Until Remission/ } \\
\text { Relapse/Duration } \\
\text { of Treatment }\end{array}$ & $\begin{array}{l}\text { Special } \\
\text { aspects }\end{array}$ \\
\hline \multirow[t]{7}{*}{ 1) } & \multirow[t]{7}{*}{$3 / \mathrm{M}$} & Generalized & + & DIF: IgG, C3 (BM) & Anti BP180 & $10.4 \times 10^{9} / /(10)$ & a) Prednisolone & $\begin{array}{l}\text { Initially rapid response } \\
\text { with disease control }\end{array}$ & Family history of atopy \\
\hline & & \multirow[t]{6}{*}{$\mathrm{HF}+$} & & IIF: IgG (BR) & $136 \mathrm{U} / \mathrm{ml}$ & At relapse: & $2 \mathrm{mg} / \mathrm{kg} / \mathrm{d} \rightarrow 1 \mathrm{mg} / \mathrm{kg} / \mathrm{d}$ & $\begin{array}{l}\text { Relapse within } 2 \text { weeks } \\
\text { after diagnosis on systemic } \\
\text { prednisolone }(2 \mathrm{mg} / \mathrm{kg}) \\
\text { and during respiratory } \\
\text { tract infection }\end{array}$ & Rotavirus vaccine \\
\hline & & & & \multirow[t]{5}{*}{ IB: $180 k D$ pos. } & $($ norm $<9)$ & $54 \times 10^{9} / 1(52)$ & b) Dapsone $2 \mathrm{mg} / \mathrm{kg} / \mathrm{d}$ & $\begin{array}{l}\text { Slow response after relapse, } \\
\text { need for multiple medications }\end{array}$ & 4 weeks prior \\
\hline & & & & & At relapse: & \multirow[t]{4}{*}{$\mathrm{Tc}>1000 \times 10^{9} / \mathrm{l}$} & c) $I V I G 1 \mathrm{~g} / \mathrm{kg} \times 3$ & $\begin{array}{l}\text { Response to dapsone after } \\
2.5 \text { weeks }\end{array}$ & \\
\hline & & & & & Anti BP180 & & \multirow[t]{3}{*}{ d) $\operatorname{MMF}\left(2 \times 600 \mathrm{mg} / \mathrm{m}^{2} / \mathrm{d}\right)$} & \multirow{3}{*}{$\begin{array}{l}\text { Duration of treatment: } \\
8 \text { months }\end{array}$} & \\
\hline & & & & & $189 \mathrm{U} / \mathrm{ml}$ & & & & \\
\hline & & & & & Anti BP230 neg. & & & & \\
\hline \multirow[t]{4}{*}{ 2) } & \multirow[t]{4}{*}{$3 / \mathrm{M}$} & \multirow[t]{4}{*}{$\begin{array}{l}\text { Localized with few } \\
\text { disseminated lesions HF+ }\end{array}$} & \multirow[t]{4}{*}{-} & DIF: lgG, C3 (BM) & Anti BP180 & \multirow[t]{4}{*}{$16.1 \times 10^{9} / 1(23)$} & a) Topical Prednicarbate & $\begin{array}{l}\text { Good response to topical } \\
\text { treatment within days }\end{array}$ & \\
\hline & & & & IIF: IgG (BR) & $90 \mathrm{U} / \mathrm{ml}$ & & (mid-potency corticosteroid) & No relapse & \\
\hline & & & & \multirow[t]{2}{*}{ IB: 180kD pos. } & $($ norm < 9$)$ & & & \multirow{2}{*}{$\begin{array}{l}\text { Duration of treatment: } \\
4 \text { weeks }\end{array}$} & \\
\hline & & & & & Anti BP230 neg. & & & & \\
\hline \multirow[t]{4}{*}{ 3) } & \multirow[t]{4}{*}{$4 / \mathrm{M}$} & Generalized & \multirow[t]{4}{*}{-} & DIF: IgG, C3 (BM) & Anti BP180 & \multirow[t]{4}{*}{$23.4 \times 10^{9} / /(20)$} & a) Prednisolone & $\begin{array}{l}\text { Complete remission } \\
\text { within } 1 \text { week }\end{array}$ & Vaccination 4 weeks prior \\
\hline & & \multirow[t]{3}{*}{$\mathrm{HF}+$} & & IIF: IgG (BR) & $156 \mathrm{U} / \mathrm{ml}$ & & $2 \mathrm{mg} / \mathrm{kg} / \mathrm{d} \rightarrow 1 \mathrm{mg} / \mathrm{kg} / \mathrm{d}$ & $\begin{array}{l}\text { Weaning of steroids } \\
\text { within } 3 \text { months }\end{array}$ & (DPTP, HiB, HepB, Rotavirus) \\
\hline & & & & IB: $180 k D$ pos. & $($ norm < 9$)$ & & b) Dapsone $1.5 \mathrm{mg} / \mathrm{kg} / \mathrm{d}$ & No relapse & \\
\hline & & & & & Anti BP230 neg. & & & $\begin{array}{l}\text { Duration of treatment: } \\
6 \text { months }\end{array}$ & \\
\hline \multirow[t]{6}{*}{ 4) } & \multirow[t]{6}{*}{$3 / F$} & Generalized & \multirow[t]{6}{*}{-} & DIF: IgG, C3 (BM) & Anti BP180 & $25.1 \times 10^{9} / /(13)$ & a) Prednisolone & $\begin{array}{l}\text { Slow response to } \\
\text { prednisolone } 1 \mathrm{mg} / \mathrm{kg}\end{array}$ & Rotavirus vaccine \\
\hline & & $\mathrm{HF}+$ & & IF: $\lg G(B R)$ & $125 \mathrm{U} / \mathrm{ml}$ & Tc $860 \times 10^{9} / /$ & $2 \mathrm{mg} / \mathrm{kg} / \mathrm{d} \rightarrow 1 \mathrm{mg} / \mathrm{kg} / \mathrm{d}$ & $\begin{array}{l}\text { Rapid response to } \\
\text { oral betamethasone } \\
0.3 \mathrm{mg} / \mathrm{kg} / \mathrm{d}\end{array}$ & 4 weeks prior \\
\hline & & & & IB: $180 k D$ pos. & $($ norm < 9$)$ & & b) Systemic betamethasone & $\begin{array}{l}\text { No relapse upon } \\
\text { glucocorticoid tapering }\end{array}$ & Arterial hypertension \\
\hline & & & & & Anti BP230 neg. & & $0.3 \mathrm{mg} / \mathrm{kg} / \mathrm{d}$ & $\begin{array}{l}\text { Complete remission under } \\
\text { dapsone } 0.5 \mathrm{mg} / \mathrm{kg} / \mathrm{d}\end{array}$ & Myocardial hypertrophy \\
\hline & & & & & & & c) Dapsone & Treatment ongoing & $\rightarrow$ Propranolol \\
\hline & & & & & & & $1 \mathrm{mg} / \mathrm{kg} / \mathrm{d} \rightarrow 0.5 \mathrm{mg} / \mathrm{kg} / \mathrm{d}$ & & \\
\hline
\end{tabular}


Table 1 Clinical and laboratory findings of the patient cohort (Continued)

\begin{tabular}{|c|c|c|c|c|c|c|c|}
\hline \multirow[t]{4}{*}{ 5) $7 / \mathrm{M}$} & Generalized & - & DIF: IgG, C3 (BM) & Anti BP180 & $27.3 \times 10^{9} / /(9)$ & $\begin{array}{l}\text { a) Prednisolone } 1 \rightarrow \\
0.5 \mathrm{mg} / \mathrm{kg} / \mathrm{d}\end{array}$ & $\begin{array}{l}\text { Rapid response to oral } \\
\text { betamethasone }\end{array}$ \\
\hline & $\mathrm{HF}+$ & & IIF: IgG (BR) & $154 \mathrm{U} / \mathrm{ml}$ & Tc $599 \times 10^{9} / 1$ & b) Systemic betamethasone & Full remission after 2 months \\
\hline & & & IB: 180kD pos. & $($ norm < $<$ ) & & $0.4 \mathrm{mg} / \mathrm{kg} / \mathrm{d} \rightarrow 0.2 \mathrm{mg} / \mathrm{kg} / \mathrm{d}$ & No relapse \\
\hline & & & & Anti BP230 neg. & & c) Dapsone 0.5 mg/kg/d & Treatment ongoing \\
\hline
\end{tabular}
c) Dapsone $0.5 \mathrm{mg} / \mathrm{kg} / \mathrm{d}$

$$
\text { Treatment ongoing }
$$

HF: Hands/Feet + present, - not present; OM: Involvement of oral mucosa; + present, - not present; DIF: Direct immunofluorescence microscopy; IIF: Indirect immunofluorescence microscopy; IB: Immunoblot; BM: basement membrane; BR: Blister roof; WBC White blood cell count; Eos: eosinophil granulocytes; Tc: thrombocytes; DPTP: Diphteria, Pertussis, Tetanus, Poliovirus; HiB: Haemophilus influenzae type b;

HepB: Hepatitis B.

Generalized disease $=$ Moderately severe and severe disease. 


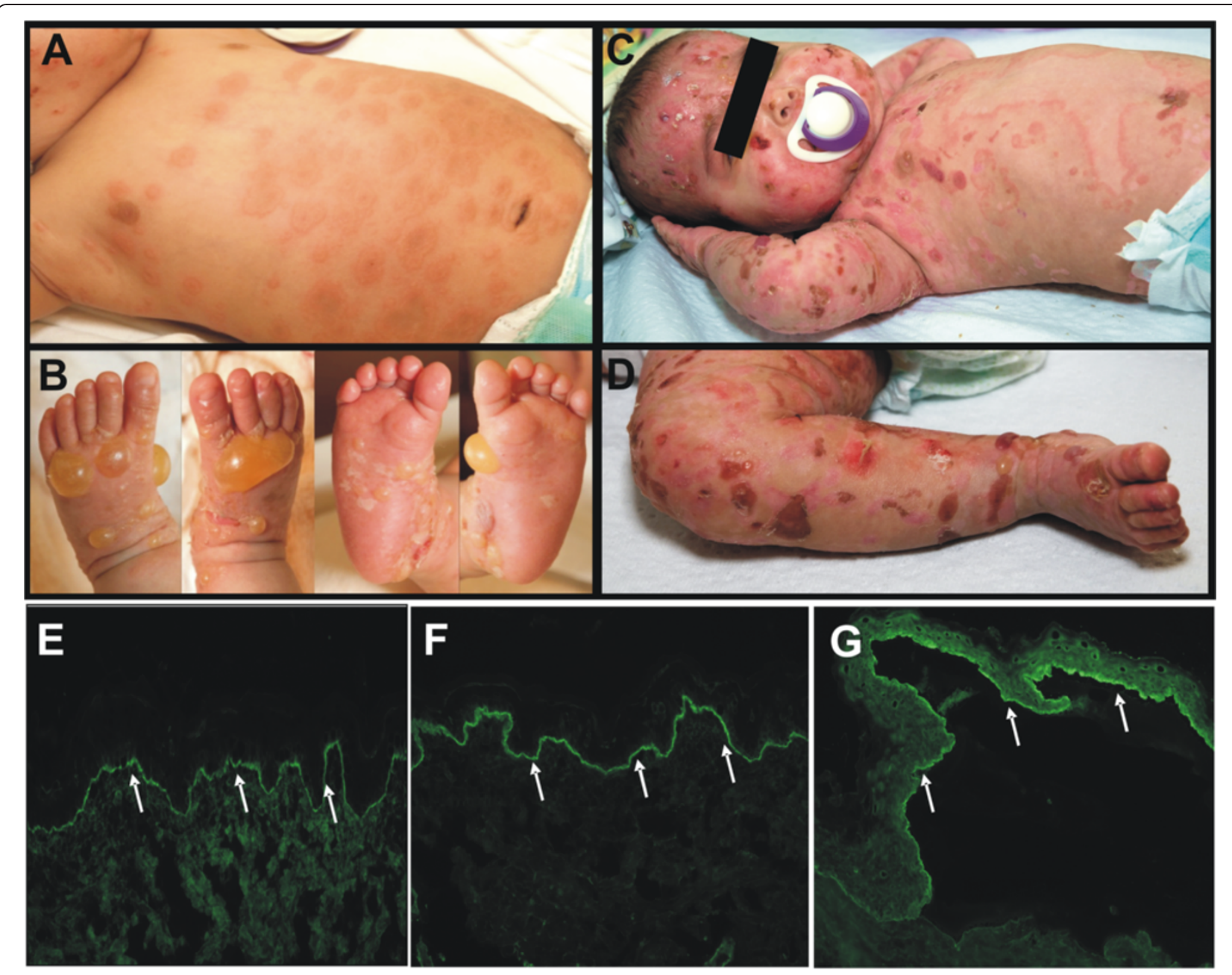

Figure 1 Clinical and diagnostic hallmarks of infantile BP. Patient 1 at initial presentation: A, urticarial plaques on the trunk. B, firm blisters and bullae on the hands and feet. C, D, Patient 1 after relapse with severe blistering on $2 \mathrm{mg} / \mathrm{kg}$ prednisolone daily. Direct immunofluorescence microscopy: $\mathbf{E}$, linear $\lg \mathbf{G}$ and $\mathbf{F}$, linear C3c depositions along the basement membrane zone (white arrows, 200x original magnification). G, indirect immunofluorescence on salt-split skin reveals circulating lgG antibodies that bind to the blister roof, which is diagnostic for BP (white arrows, 200X original magnification).

epidermal side of the salt-split skin (Figure 1G). ELISA testing with recombinant NC16A domain of BP180 was strongly positive $(136 \mathrm{U} / \mathrm{ml}$, norm $<9 \mathrm{U} / \mathrm{ml})$. The findings were diagnostic for BP.

Initially, we treated with potent topical corticosteroids and oral antihistamines, which did not lead to significant improvement. After confirmation of the diagnosis, a treatment with prednisolone up to $2 \mathrm{mg} / \mathrm{kg} /$ day was initiated. After a brief period of clinical improvement and disease control, the patient had a respiratory tract infection in the course of which he developed severe blistering. At this time he was still on $2 \mathrm{mg} / \mathrm{kg}$ prednisolone daily (Figure 1C, D). Peripheral blood count showed leucocytosis with a maximum of $54 \mathrm{G} / \mathrm{l}$ ( $52 \%$ eosinophils) and significant reactive thrombocytosis (>1000 G/l) with signs of increased coagulation activity necessitating treatment with acetylsalicylic acid. The ELISA value for BP180- specific antibodies at this point was $189 \mathrm{U} / \mathrm{ml}$. After confirming normal glucose-6-phosphate dehydrogenase levels, we added dapsone at a maximum dose of $2 \mathrm{mg} / \mathrm{kg}$ daily, controlling for the development of methemoglobinemia. As the blistering continued to progress, we added intravenous immunoglobulins (IVIG) $1 \mathrm{~g} / \mathrm{kg}$ three times. Yet the patient developed more cutaneous and additionally intraoral blisters causing refusal of oral intake. He also developed persistent hoarseness, but laryngeal involvement of the BP could be excluded.

After two weeks of worsening, we added oral mycophenolate mofetil (MMF) at a dose of $625 \mathrm{mg} / \mathrm{m}^{2}$ twice daily (MMF local dosing regimen, note that recommended standard dose in children is $600 \mathrm{mg} / \mathrm{m}^{2}$ twice daily). Within days, the patient's skin improved and the number of new lesions decreased. We interpreted this improvement as delayed response to dapsone rather 
than response to MMF, which usually takes several weeks to set in. Over the following weeks, we slowly weaned the patient off systemic corticosteroids and then reduced the MMF dose in two steps over two months. After another two months of clinical remission, we also stopped treatment with dapsone. After 12 months the patient was off all medication. Anti-BP180 antibody values significantly decreased over the course of three months, parallel to clinical improvement. Also, the number of leukocytes (including eosinophils) and thrombocytes decreased and normalized. At the time of submission, the patient had been free of symptoms for two years. Due to parental fear of relapse, the patient had not received any further vaccinations.

\section{Analysis of all reported infantile BP cases, including own patient cohort \\ Clinical characteristics}

The literature review of all obtainable reports between the years 1977 and 2013 including our own cases revealed 53 reports $[8,11-14,22-68]$ with a total of 81 cases of $\mathrm{BP}$ occurring in children within the first year of life but beyond the neonatal period (Additional file 1: Table S1). While very few cases were reported before the year 2000, there has been a significant increase since then (Additional file 2: Figure S1). The mean and median age was approximately four months with $64 \%$ of cases between three to five months. The gender ratio male to female was 39 to 38. In four cases gender was not stated. Moderately severe and severe (generalized) disease ( $>10 \%$ body surface area - BSA) was seen in $83.9 \%$ of cases $(n=68$ of 81$)$. All children showed at least some involvement of the hands and feet. Mucosal blistering was present in $14.8 \%$ of cases $(n=12$ of 81$)$; four of these patients had severe disease (Table 2).

98\% ( $\mathrm{n}=79$ of 81$)$ of children affected had previously been healthy. One patient had a congenital T-cell lymphocytopenia and one child had been diagnosed with Hyper IgE-syndrome. The general condition at the time of presentation was good in the majority of cases; some patients were irritable, likely due to pruritus. However, one child with a very delayed initiation of appropriate treatment presented with significant morbidity, including severe weight loss, dehydration and failure to thrive, as well as developmental delay [41]. One of our own patients was also severely affected during a relapse where he refused oral intake and lost weight (see index case above). Both children improved quickly once sufficient treatment was established.

Twenty five children (30.8\%) had been vaccinated within days or weeks prior to the onset of disease, the majority with the standard mix of passive vaccines recommended in this age group. Two of our five own cases had received a newly recommended oral vaccine against Rotavirus prior

Table 2 Clinical characteristics of all reported infantile BP cases, including own patient cohort

\begin{tabular}{|c|c|c|}
\hline No of cases & $\mathrm{N}=81$ & Comments \\
\hline Mean (median) age/age range & 4.5 (4) months/1-12 months & \\
\hline Gender M/F & 39/38 (4 unknown) & \\
\hline \multicolumn{3}{|l|}{ Extent of skin in involvement } \\
\hline - Localized/mild disease (+/- few disseminated plaques) & $N=10(12.3 \%)$ & \\
\hline - Generalized/moderately severe and severe disease & $N=68(83.9 \%)$ & \\
\hline$\cdot \mathrm{N} / \mathrm{A}$ & $N=3(3.7 \%)$ & \\
\hline - Involvement of hands and feet & $N=81(100 \%)$ & \\
\hline \multirow[t]{2}{*}{ Involvement of oral mucosa (with generalized disease) } & \multirow[t]{2}{*}{$N=12(14.8 \%)$} & $\begin{array}{l}\text { All children with oral lesions had generalized } \\
\text { skin involvement }\end{array}$ \\
\hline & & Severe disease $N=5$ \\
\hline No of children vaccinated prior to onset & $N=25(30.8 \%)$ & \\
\hline - DPTP +/- others, & $N=22$ & \multirow{3}{*}{$\begin{array}{l}\text { Latency between vaccination and onset of } \\
\text { disease: } 1 \text { day - } 4 \text { weeks }\end{array}$} \\
\hline - Rotavirus, & $N=2$ & \\
\hline - DPTP plus Rotavirus & $N=1$ & \\
\hline No of patients with a relapse & $N=12(14.8 \%)$ & \\
\hline \multicolumn{3}{|l|}{ Outcome } \\
\hline - Cured & $N=76(93.8 \%)$ & \\
\hline - In remission under treatment at time of report & $N=3(3.7 \%)$ & \\
\hline - Still symptomatic at time of report & $N=1(1.2 \%)$ & \\
\hline • Death & $N=1(1.2 \%)$ & Patient had congenital immune deficiency \\
\hline
\end{tabular}

N/A: Not Available; DPTP: Diphteria, Pertussis, Tetanus, Poliovirus. 
to the onset of disease. This has not been reported before. In two children a febrile infection was reported prior to the onset of disease [37] or prior to a relapse [27], this report.

\section{Pathophysiology and diagnostic features}

Histology, if reported, showed dermal edema, an inflammatory infiltrate dominated by eosinophils and subepidermal blistering. DIF showed IgG and/or C3 along the basement membrane in 72 cases (90\%), in 12 cases (15\%) there were additional IgA deposits, in four cases there were IgM- and in one case IgE-deposits. In immunoblot analyses reported in 20 patients, 15 sera recognized a $180 \mathrm{kDa}$ protein, five sera recognized a $230 \mathrm{kDa}$ protein, and one serum both.

ELISA values were reported in only 21 (25.9\%) cases. All of these patients had antibodies against the NC16Adomain of BP180; two also had additional anti-BP 230 antibodies. Comparison of ELISA values of reported cases from different centers is not fully possible because of different commercial and non-commercial ELISA systems used. In our own cohort, BP180 NC16A ELISA values in infantile patients were significantly higher than in a control group of 28 adults newly diagnosed with BP in our center in the same time period (Figure 2). Extremely high values in our cohort and in reported patients seemed to be associated with more extensive disease and the need for systemic treatment.

A blood cell count was reported in 37 patients, the mean white blood cell count was 23.9 G/l (range $<10$ -

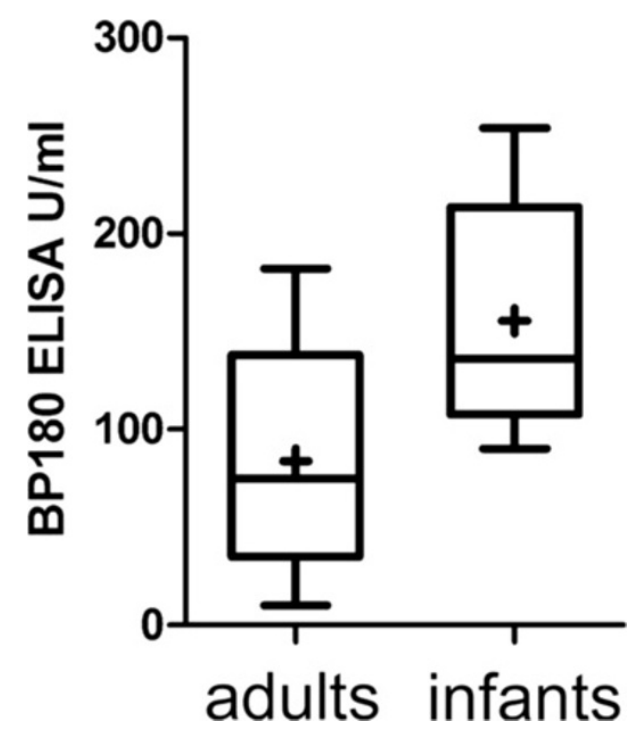

Figure 2 ELISA values in infantile and adult BP. Anti-BP180 ELISA values in our infantile BP cohort were significantly higher, compared to a control group of newly diagnosed adult BP patients (normal value $<9 \mathrm{U} / \mathrm{ml}$; boxplot analysis; whiskers: minimum and maximum values; bottom and top of boxes: first and third quartiles; band inside box: median; cross: mean).
120G/l, median 19.4). The percentage of eosinophils had a mean of $23 \%$ (range $7-66 \%$, median 19\%).

\section{Treatment modalities}

The majority of patients were treated with systemic corticosteroids (50.6\%) with or without additional erythromycin or other antibiotics. $19.8 \%$ of patients were treated with a combination of systemic corticosteroids and dapsone or sulfapyridine, and $9.9 \%$ were treated with topical corticosteroids alone. $13.7 \%$ of patients $(n=11)$ needed a combination of multiple agents (Table 3). All but one patient reached remission eventually. However, the patient with concomitant congenital T-cell lymphocytopenia died from unknown cause three months after having received two doses of rituximab for severe disease. Relapses were not common $(14.8 \%, \mathrm{n}=12)$ (Table 3 and Additional file 3: Table S2).

\section{Discussion}

Infantile BP is considered very rare. Prospective studies are therefore difficult to perform. Incidence in Israel was estimated to be $2.36: 100,000$ per year [13]; however, in most countries no central registry exists and the disease might be under-recognized. We present a detailed characterization of a current cohort of five infants with BP from our departments. Furthermore we performed a comprehensive analysis of all cases reported in the literature (age 1-12 months) with respect to clinical and laboratory characteristics and treatment modalities. Taken together the results allow for the following conclusions.

\section{Diagnostic features}

Laboratory test results in infantile BP generally resemble those in adult BP. Linear IgG and/or C3 depositions at the basement membrane in DIF are the diagnostic hallmark. Autoantibody profiles, as detected by various methods, are comparable to those in adults with BP [69]: autoantibodies against the NC16A domain of BP180 are more frequent than anti-BP230 antibodies.

We propose the following minimal diagnostic criteria for infantile BP: typical clinical picture (urticarial plaques and blisters, acral distribution) and linear IgG and/or C3 deposition at the basement membrane in DIF. Further diagnostic pointers are the presence of serum autoantibodies against BP180 and/or BP230. and - even though less specific - subepidermal blistering with an eosinophil rich inflammatory infiltrate in conventional histology.

Even though ELISA results were only reported in a minority of cases, and different test systems used do not allow for direct comparison, the reported autoantibody levels in infants seem fairly high. Comparing ELISA values of our five infants with a control group of 28 adults newly diagnosed with BP in our center in the same time period, we found that the mean and median 
Table 3 Treatment Modalities of Infantile BP Patients

\begin{tabular}{|c|c|c|}
\hline Treatment & No of cases $(\%$ of total $\mathrm{N}=81$ ) & Comments \\
\hline Topical corticosteroids alone & $N=8(9.9 \%)$ & Good response \\
\hline Topical corticosteroids + IVIG & $N=1(1.2 \%)$ & Several relapses for one year \\
\hline Topical corticosteroids + erythromycin & $\mathrm{N}=1(1.2 \%)$ & Good response \\
\hline Systemic $+/-$ topical corticosteroids ( $+/-$ antibiotics) & $N=41(50.6 \%)$ & Good response \\
\hline $\begin{array}{l}\text { Systemic corticosteroids + dapsone/ sulphapyridin } \\
\text { (+/- antibiotics) }\end{array}$ & $N=16(19.8 \%)$ & Good response \\
\hline Dapsone/ sulphapyridin alone & $\mathrm{N}=2(2.5 \%)$ & $\begin{array}{l}\text { One relapse under treatment. } \\
\text { Same treatment was attempted in } \\
\text { one other patient without success, sc } \\
\text { steroids were added. }\end{array}$ \\
\hline No treatment & $N=1$ & \\
\hline N/A & $N=1$ & \\
\hline $\begin{array}{l}\text { Corticosteroids }+/- \text { dapsone plus other medications } \\
\text { due to poor response }\end{array}$ & $N=11(13.7 \%)$ & \\
\hline - Azathioprine & $N=1$ & No response \\
\hline - Cyclosporine & $N=2$ & $\begin{array}{l}\text { Good response in } N=1 \\
\text { Partial response in } N=1\end{array}$ \\
\hline - Mycophenolate mofetil & $N=7$ & Moderate response in $\mathrm{N}=7$ \\
\hline - Erythromycin and nicotinamide & $N=8$ & $\begin{array}{l}\text { Good response in } N=3 \\
\text { Partial / uncertain response in } N=5\end{array}$ \\
\hline$\cdot \operatorname{IVIG}$ & $N=8$ & $\begin{array}{l}\text { Good response in } N=2 \\
\text { Partial/ uncertain response in } N=6\end{array}$ \\
\hline - Rituximab & $N=3$ & $\begin{array}{l}\text { Good response } N=2 \text {. } \\
\text { Partial response } N=1 \text {. } \\
\text { One sudden death in one of those } \\
\text { two patients after three months } \\
\text { (child had congenital immune } \\
\text { deficiency). }\end{array}$ \\
\hline - Omalizumab & $N=1$ & Good response \\
\hline
\end{tabular}

IVIG: Intravenous immunoglobulins.

levels of anti-BP180 NC16A antibody levels in infants were significantly higher. These ELISA values had been measured with the same test system (see Methods).

The clinical relevance of antibody testing in infantile BP has been contested [14]. Nevertheless - when tested patients with a more recalcitrant disease course demonstrated high autoantibody levels. In our cohort, higher values at presentation correlated with the need for more aggressive and longer-term treatment, and values increased before relapses. Therefore, it appears reasonable to take into account the levels of BP180-specific autoantibodies in infantile $\mathrm{BP}$ when making treatment decisions.

\section{Patient characteristics/clinical features}

At disease onset, the mean age of children was around four months. As opposed to previous reports [13], there was no significant female predominance.

No common trigger was identified. A large number of patients had either been vaccinated or suffered an infection prior to the onset or relapse of disease (Table 2, Additional file 1: Table S1 and Additional file 3: Table S2). The type of infection or vaccine varied. It can be speculated that a modulation of the immune system might play a role in triggering or unmasking an underlying subclinical BP. Nevertheless, especially due to the high number of infants receiving vaccination, this association might be purely coincidental and we believe that the term postvaccination infantile BP should be used with caution.

Cases of adult BP associated with malignancy exist, even though the causal relation remains unclear. In

Table 4 Important Differential Diagnoses of Infantile BP

\begin{tabular}{ll}
\hline Autoimmune blistering skin diseases & $\cdot$ Linear IgA dermatosis \\
& $\cdot$ Epidermolysis bullosa acquisita \\
Hereditary & Epidermolysis bullosa \\
& $\cdot$ Porphyria \\
Infectious & $\cdot$ Bullous impetigo \\
Others & - Pompholyx \\
& $\cdot$ Bullous mastocytosis \\
& $\cdot$ Insect bites \\
& $\cdot$ Insect bite like reaction of \\
& hematologic malignancy \\
\hline
\end{tabular}


contrast, no case of infantile BP in relation with a malignant neoplasm has been reported. Furthermore, unlike in adult BP [70,71], drugs do not seem to play a major role in triggering infantile $\mathrm{BP}$.
Within the age group of four weeks to 12 months, the clinical picture was moderately severe to severe (generalized) in over $80 \%$ of cases. Acral blistering was present in all children, while mucosal involvement was uncommon. In

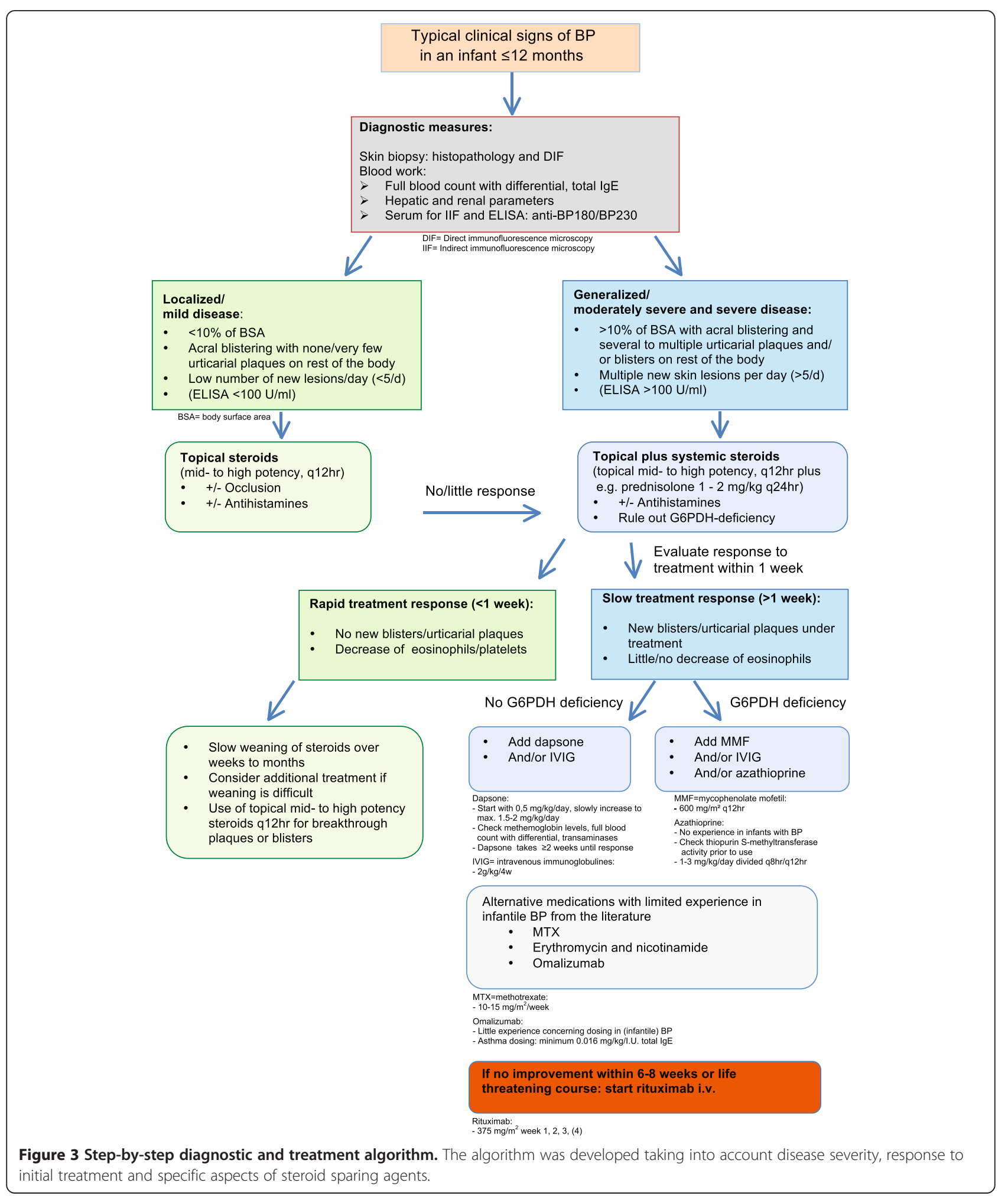


localized disease, hands and feet were usually affected. There was no case of isolated genital infantile BP. Taken together, involvement of the hands and feet can be considered as a clinical hallmark and diagnostic clue of infantile BP. This is in contrast to childhood and adult BP $[1,4,69]$. Important differential diagnoses of infantile BP are listed in Table 4.

Most infants were doing well at the time of presentation despite some irritability, likely due to pruritus. However, individual children with significant morbidity including difficulty breathing and feeding, and weight loss, have been reported.

Even though initial presentation is often severe, the prognosis of infantile BP is excellent, with all but one patient reaching complete remission. That child had only been followed up short-term at the time of publication [8] and subsequent remission is possible. One infant passed away shortly after having been discharged from hospital. This child had received several doses of rituximab and had an underlying immune deficiency, which might have played a role.

The number of relapses was low. It seems that relapses can be triggered by infections or that they occurred in patients where tapering of corticosteroids was started early. Also, relapses were more frequent in patients who did not receive systemic corticosteroids (Additional file 3: Table S2). Once the disease has been controlled for several months, the likelihood of a relapse is extremely small.

\section{Treatment algorithm}

In contrast to adult BP, no treatment guidelines for infantile BP exist [15-18,72], and there has been little discussion on possible criteria for choosing the right treatment. After a comprehensive analysis of reported treatments in all published cases of infantile BP - together with lessons learned from our own cohort - we propose a first treatment algorithm. This step-by-step diagnostic and treatment algorithm takes into account disease severity, response to initial treatment and specific practical aspects of steroid sparing agents. It is based on general experience with the different medications in infants and the treatment recommendations published for adult BP (Figure 3).

After the diagnosis is established, all patients should receive treatment with mid- to high-potency topical corticosteroids. Children with moderately severe or severe disease (generalized, $>10 \%$ BSA) usually require additional treatment with systemic corticosteroids. If the treatment response is slow or high doses of corticosteroids are needed for disease control, additional steroid sparing agents should be considered. Dapsone seems to be the agent of choice as it is usually well tolerated, effective, and is frequently used for other autoimmune blistering diseases of infancy and childhood, such as linear IgA dermatosis. Other steroid sparing agents used are IVIGs and MMF. Little or no experience exists for erythromycin-, methotrexate-, cyclophosphamide or azathioprine treatment in infants with BP. Rituximab is to be reserved as rescue treatment for the most severe cases $[49,67]$. The full potential and dosing of omalizumab in infantile BP warrant further investigation [56,73].

After clinical remission for several months, treatment discontinuation can be considered. In our experience ELISA autoantibody values can take a long time to normalize and are therefore not always helpful for deciding when to end treatment.

\section{Conclusions}

Infantile BP is considered a rare disorder; however an increasing number of reports during the last years show that it might have been under-recognized. As the disorder is not well known to general pediatricians and dermatologists, most infants are not promptly diagnosed and undergo multiple examinations before establishment of the correct diagnosis.

Infantile BP presents with urticarial plaques and blisters. Involvement of hands and feet is present in all cases. The clinical picture of infantile BP is characteristic. It is therefore a realistic aim to make the diagnosis early, avoid unnecessary diagnostic measures, and treat appropriately to avoid severe morbidity.

Pathogenesis and diagnostic criteria are comparable to adult BP, yet ELISA levels seem to be higher in infants. The overall disease outcome is favorable. Based on the results of this study we have established a first step-bystep diagnostic and treatment algorithm, taking into account disease severity, response to initial treatment and specific aspects of steroid sparing agents.

\section{Additional files}

Additional file 1: Table S1. All cases of infantile BP in the literature and this study.

Additional file 2: Figure S1. The number of published infantile BP cases has significantly increased since 2000 .

Additional file 3: Table S2. Relapses of infantile BP.

\section{Abbreviations}

BP: Bullous pemphigoid; BP180: Bullous pemphigoid 180 kDa antigen/ collagen XVII; BP230: Bullous pemphigoid 230 kDa antigen; BSA: Body surface area; DIF: Direct immunofluorescence microscopy; IIF: Indirect immunofluorescence microscopy; IVIG: Intravenous immunoglobulins; MMF: Mycophenolate mofetil.

\section{Competing interests}

The authors declare that they have no competing interests.

\section{Authors' contributions}

ASB and JSK conceptualized and designed the study, collected and analyzed the entire data, drafted the manuscript and approved the final manuscript as submitted. CM, HO, BM, FS and DK contributed clinical data, helped with data analysis and approved the final manuscript as submitted. ES and CS contributed diagnostic data, helped with data analysis and approved the 
final manuscript as submitted. All the authors revised and accepted the final version of the manuscript.

\section{Acknowledgments}

We would like to thank the patients and their families for participating in this study. We would further like to thank A. Bedorf and K. Thoma for expert technical assistance. The article processing charge was funded by the German Research Foundation (DFG) and the Albert Ludwigs University Freiburg in the funding program Open Access Publishing.

\section{Author details}

${ }^{1}$ Departments of Dermatology and Pediatrics, Medical Center - University of Freiburg, Freiburg, Germany. ${ }^{2}$ Children's Hospital "Klinik am Eichert", Goeppingen, Germany. ${ }^{3}$ Department of Dermatology, University of Luebeck, Luebeck, Germany. ${ }^{4}$ Catholic Children's Hospital Wilhelmstift, Hamburg, Germany. ${ }^{5}$ Department of Dermatology, Medical Center - University of Freiburg, Hauptstrasse 7, Freiburg 79104, Germany.

Received: 22 August 2014 Accepted: 7 November 2014

Published online: 10 December 2014

\section{References}

1. Schmidt E, Zillikens D: Pemphigoid diseases. Lancet 2013, 381:320-332.

2. Di Zenzo G, Della Torre R, Zambruno G, Borradori L: Bullous pemphigoid: from the clinic to the bench. Clin Dermatol 2012, 30:3-16.

3. Murrell DF, Daniel BS, Joly P, Borradori L, Amagai M, Hashimoto T, Caux F, Marinovic B, Sinha AA, Hertl M, Bernard P, Sirois D, Cianchini G, Fairley JA, Jonkman MF, Pandya AG, Rubenstein D, Zillikens D, Payne AS, Woodley D, Zambruno G, Aoki V, Pincelli C, Diaz L, Hall RP, Meurer M, Mascaro JM Jr, Schmidt E, Shimizu H, Zone J, et al: Definitions and outcome measures for bullous pemphigoid: recommendations by an international panel of experts. J Am Acad Dermatol 2012, 66:479-485.

4. Kneisel A, Hertl M: Autoimmune bullous skin diseases. Part 1: clinical manifestations. J Dtsch Dermatol Ges 2011, 9:844-856. quiz 857.

5. Yeh SW, Ahmed B, Sami N, Razzaque Ahmed A: Blistering disorders: diagnosis and treatment. Dermatol Ther 2003, 16:214-223.

6. Langan SM, Smeeth L, Hubbard R, Fleming KM, Smith CJP, West J: Bullous pemphigoid and pemphigus vulgaris-incidence and mortality in the UK: population based cohort study. BMJ 2008, 337:a180.

7. Joly P, Baricault S, Sparsa A, Bernard P, Bédane C, Duvert-Lehembre S, Courville $P$, Bravard P, Rémond B, Doffoel-Hantz V, Bénichou J: Incidence and mortality of bullous pemphigoid in France. J Invest Dermatol 2012, 132:1998-2004.

8. Fisler RE, Saeb M, Liang MG, Howard RM, McKee PH: Childhood bullous pemphigoid: a clinicopathologic study and review of the literature. Am J Dermatopathol 2003, 25:183-189.

9. Lara-Corrales I, Pope E: Autoimmune blistering diseases in children. Semin Cutan Med Surg 2010, 29:85-91.

10. Bean SF, Good RA, Windhorst DB: Bullous pemphigoid in an 11-year-old boy. Arch Dermatol 1970, 102:205-208.

11. Gould WM, Zlotnick DA: Bullous pemphigoid in infancy: a case report. Pediatrics 1977, 59:942-945.

12. Nemeth AJ, Klein AD, Gould EW, Schachner LA: Childhood bullous pemphigoid. Clinical and immunologic features, treatment, and prognosis. Arch Dermatol 1991, 127:378-386.

13. Waisbourd-Zinman O, Ben-Amitai D, Cohen AD, Feinmesser M, Mimouni $D$ Adir-Shani A, Zlotkin M, Zvulunov A: Bullous pemphigoid in infancy: clinical and epidemiologic characteristics. J Am Acad Dermato/ 2008, 58:41-48.

14. Brazzelli V, Grasso V, Bossi G, Borroni G: Is there a role for the detection of autoantibodies in the clinical practice of treating infants with bullous pemphigoid? A case report. Pediatr Dermatol 2013. [Epub ahead of print].

15. Wojnarowska F, Kirtschig G, Highet AS, Venning VA, Khumalo NP, British Association of Dermatologists: Guidelines for the management of bullous pemphigoid. Br J Dermatol 2002, 147:214-221.

16. Bernard $P$, Bedane $C$, Prost $C$, Ingen-Housz-Oro $S$, Joly $P$, Centres de référence des maladies bulleuses auto-immunes. Société Française de Dermatologie: [Bullous pemphigoid. Guidelines for the diagnosis and treatment]. Centres de référence des maladies bulleuses auto-immunes. Société Française de Dermatologie]. Ann Dermatol Venereol 2011, 138:247-251.

17. Kirtschig G, Middleton P, Bennett C, Murrell DF, Wojnarowska F, Khumalo NP: Interventions for bullous pemphigoid. Cochrane Database Syst Rev 2010, 6(10):CD002292.
18. Fuertes De Vega I, Iranzo-Fernández P, Mascaró-Galy JM: Bullous pemphigoid: clinical practice guidelines. Actas Dermosifiliogr 2014, 105:328-346.

19. Sitaru C, Schmidt E, Petermann S, Munteanu LS, Bröcker E-B, Zillikens D: Autoantibodies to bullous pemphigoid antigen 180 induce dermalepidermal separation in cryosections of human skin. J Invest Dermatol 2002, 118:664-671.

20. Kern JS, Gehring W, Kreisel W, Hertl M, Technau-Hafsi K, Bruckner-Tuderman L, Hofmann SC: Overlap of IgA pemphigus and linear IgA dermatosis in a patient with ulcerative colitis: a mere coincidence? Acta Derm Venereol 2014, 94(2):228-230.

21. Hofmann SC, Voith U, Sasaki T, Trüeb RM, Nischt R, Bruckner-Tuderman L: The autoantigen in anti-p200 pemphigoid is synthesized by keratinocytes and fibroblasts and is distinct from nidogen-2. J Invest Dermatol 2008, 128:87-95.

22. Marsden RA, McKee PH, Bhogal B, Black MM, Kennedy LA: A study of benign chronic bullous dermatosis of childhood and comparison with dermatitis herpetiformis and bullous pemphigoid occurring in childhood. Clin Exp Dermatol 1980, 5:159-176.

23. Hernández-Aguado I, Sánchez-Pedreño-Guillén P, Moreno-Giménez JC, Camacho-Martínez F: [Bullous pemphigoid in a 5-month-old infant]. Med Cutan Ibero Lat Am 1982, 10:391-394.

24. Marsden RA: Bullous pemphigoid in a child. Clin Exp Dermato/ 1983, 8:329-332.

25. Tani M, Tani M, Komura A, Murata Y: Bullous pemphigoid of childhood: report of a case and immunoelectron microscopic studies. J Am Acad Dermatol 1988, 19(2 Pt 1):366-367.

26. Oranje AP, Vuzevski VD, van Joost T, ten Kate F, Naafs B: Bullous pemphigoid in children. Report of three cases with special emphasis on therapy. Int J Dermatol 1991, 30:339-342.

27. Ostlere LS, Stevens H, Black MM, Rustin MH, Hashimoto T, Nishikawa T: Bullous pemphigoid in infancy-a case report including new immunoblotting observations. Clin Exp Dermatol 1993, 18:483-485.

28. Kirtschig G, Wojnarowska F, Marsden RA, Edwards S, Bhogal B, Black MM: Acquired bullous diseases of childhood: re-evaluation of diagnosis by indirect immunofluorescence examination on $1 \mathrm{M} \mathrm{NaCl}$ split skin and immunoblotting. Br J Dermatol 1994, 130:610-616.

29. Cambazard F, Thivolet J, Mironneau P: Bullous pemphigoid in a 4-month-old boy. Br J Dermatol 1994, 131:449-451.

30. Nagano T, Tani M, Adachi A, Takanaga T, Sakamoto S, Kodama S, Fujiwara S: Childhood bullous pemphigoid: immunohistochemical, immunoelectron microscopic, and western blot analysis. J Am Acad Dermatol 1994, 30(5 Pt 2):884-888.

31. Wisuthsarewong W, Viravan S, Kulthanan K: Bullous pemphigoid in an infant: a case report and literature review. J Med Assoc Thai 1997, 80:270-274.

32. Edwards S, Wakelin SH, Wojnarowska F, Marsden RA, Kirtschig G, Bhogal B, Black MM: Bullous pemphigoid and epidermolysis bullosa acquisita: presentation, prognosis, and immunopathology in 11 children. Pediatr Dermatol 1998, 15:184-190.

33. Cunha PR, Thomazeski PV, Hipólito E, Michalany NS, Bystryn JC: Bullous pemphigoid in a 2-month-old infant. Int J Dermatol 1998, 37:935-938.

34. Amos B, Deng JS, Flynn K, Suarez S: Bullous pemphigoid in infancy: case report and literature review. Pediatr Dermatol 1998, 15:108-111.

35. Trüeb RM, Didierjean L, Fellas A, Elias A, Borradori L: Childhood bullous pemphigoid: report of a case with characterization of the targeted antigens. J Am Acad Dermatol 1999, 40(2 Pt 2):338-344.

36. Chimanovitch I, Hamm H, Georgi M, Kroiss M, Stolz W, Apitz C, Bröcker EB, Zillikens D: Bullous pemphigoid of childhood: autoantibodies target the same epitopes within the NC16A domain of BP180 as autoantibodies in bullous pemphigoid of adulthood. Arch Dermatol 2000, 136:527-532.

37. Segurado Rodriguez M, Guerra Tapia A, Sanchez Gomez E, Rodriguez Peralto J, Vanaclocha Sebastian F, Iglesia Diez I: Penfigoide ampolloso infantil: a propósito de dos casos. Actas Dermosifiliogr 2000, 91:149-152.

38. Baykal C, Okan G, Sarica R: Childhood bullous pemphigoid developed after the first vaccination. J Am Acad Dermatol 2001, 44(2 Suppl):348-350.

39. Petronius $D$, Bergman R: Bullous pemphigoid in two young infants. Pediatr Dermatol 2002, 19:119-121.

40. Singalavanija S, Limpongsanurak W: Immunobullous diseases in Thai children: report of 24 cases. J Med Assoc Thai 2003, 86(Suppl 3):S681-S688.

41. Kuenzli S, Grimaître M, Krischer J, Saurat J-H, Calza A-M, Borradori L: Childhood bullous pemphigoid: report of a case with life-threatening course during homeopathy treatment. Pediatr Dermatol 2004, 21:160-163. 
42. Sousa B, Mota A, Morgado H, Lopes JM, Dias JA: [Bullous pemphigoid in an infant]. Acta Med Port 2005, 18:159-162.

43. Mérida C, Martínez-Escribano JA, Frías JF, Sánchez-Pedreño P, Corbalán R: [Bullous pemphigoid in an infant after vaccination]. Actas Dermosifiliogr 2005, 96:255-257.

44. Voltan E, Maeda JY, Muniz Silva MA, Maruta CW, Santi CG, de Almeida Zimbres S, Aoki V: Childhood bullous pemphigoid: report of three cases. J Dermatol 2005, 32:387-392.

45. Chiavérini C, Hamel-Teillac D, Gilbert D, Prost Y: Absence of anti-BP180 antibodies in mothers of infants with bullous pemphigoid. $\mathrm{Br} J$ Dermatol 2006, 154:839-843

46. Xiao T, Li B, Wang Y-K, He C-D, Chen H-D: Childhood bullous pemphigoid treated by i.v. immunoglobulin. J Dermatol 2007, 34:650-653.

47. Sugawara N, Nagai Y, Matsushima Y, Aoyama K, Ishikawa O: Infantile bullous pemphigoid treated with intravenous immunoglobulin therapy J Am Acad Dermatol 2007, 57:1084-1089.

48. Martinez-De Pablo Ml, González-Enseñat MA, Vicente A, Gilaberte M, Mascaró JM Jr: Childhood bullous pemphigoid: clinical and immunological findings in a series of 4 cases. Arch Dermatol 2007 143:215-220.

49. Schulze J, Bader P, Henke U, Rose MA, Zielen S: Severe bullous pemphigoid in an infant-successful treatment with rituximab. Pediatr Dermato/ 2008, 25:462-465.

50. Belhadjali H, Youssef M, Njim L, Chaabane S, Sriha B, Chakroun M, Zakhama A, Zili J: Childhood vesicular pemphigoid mimicking severe atopic dermatitis: a case report. Cutis 2009, 83:182-184.

51. Toyama T, Nakamura K, Kuramochi A, Ohyama B, Hashimoto T, Tsuchida T: Two cases of childhood bullous pemphigoid. Eur J Dermatol 2009, 19:368-371.

52. Majmudar V, Herath D, O'Toole EA, Harrison A: Bullous pemphigoid of childhood: a rare disease with diagnostic and management challenges. Clin Exp Dermatol 2010, 35:213-214

53. Khaled A, Kharfi M, Fazaa B, Kamoun MR: Bullous eruption in a five-monthold girl. CMAJ 2010, 182:1325-1327.

54. Hafiji J, Bhogal B, Rytina E, Burrows NP: Bullous pemphigoid in infancy developing after the first vaccination. Clin Exp Dermatol 2010, 35:940-941.

55. Valdivielso-Ramos M, Velázquez D, Tortoledo A, Hernanz JM: [Infantile bullous pemphigoid developing after hexavalent, meningococcal and pneumococcal vaccinations]. An Pediatr (Barc) 2011, 75:199-202.

56. Dufour C, Souillet AL, Chaneliere C, Jouen F, Bodemer C, Jullien D, Cambazard F, Joly P, Reix P: Successful management of severe infant bullous pemphigoid with omalizumab. Br J Dermatol 2012, 166:1140-1142.

57. Fuertes I, Luelmo J, Leal L, Romaní J, Sánchez S, Mascaró JM Jr: Refractory childhood pemphigoid successfully treated with rituximab. Pediatr Dermatol 2013, 30:e96-e97.

58. Barreau M, Stefan A, Brouard J, Leconte C, Morice C, Comoz F, Verneuil L: Infantile bullous pemphigoid. Ann Dermatol Venereol 2012, 139:555-558.

59. Lynch M, Devaney D, Khaw Y, O'Donnell B: Bullae of the hands, feet, and perioral area in a 3-month-old infant. Bullous Pemphigoid. Pediatr Dermatol 2013, 30:135-136.

60. Pai W, Sori T, Kikkeri NN, Athanikar SB, Dinesh US, Rai V: Childhood bullous pemphigoid in a four-month-old child. Eur J Pediatr Dermatol 2013, 23:15-18.

61. De la Fuente S, Hernández-Martín Á, de Lucas R, González-Enseñat MA, Vicente A, Colmenero I, González-Beato M, Suñol M, Torrelo A: Postvaccination bullous pemphigoid in infancy: report of three new cases and literature review. Pediatr Dermatol 2013, 30:741-744.

62. Marsden RA, Skeete MV, Black MM: The chronic acquired bullous diseases of childhood. Clin Exp Dermatol 1979, 4:227-240.

63. Zebede MS, Anhalt GJ, Nsouli TM, Nsouli SM, Bellanti JA: Diffuse bullous eruption in a 3-month-old infant. Ann Allergy 1987, 58(12-13):63-66.

64. Wang P, Chen X, Li R, Zhu X: A case of infantile bullous pemphigoid. Chin J Dermatovenereol 2010, 7:026

65. Purvis DJ, Bhogal BS, Harper Jl: Bullous pemphigoid in an infant using complementary medicine. Clin Exp Dermatol 2009, 34:195-198.

66. Erbagci Z: Childhood bullous pemphigoid in association with hyperimmunoglobulin E syndrome. Pediatr Dermatol 2008, 25:28-33.

67. Schmidt E, Seitz CS, Benoit S, Bröcker EB, Goebeler M: Rituximab in autoimmune bullous diseases: mixed responses and adverse effects. Br J Dermatol 2007, 156:352-356.

68. Santos AL, Mota AV, Ramon J, Lopes JM, Azevedo F: An infant with bullous pemphigoid. Dermatol Online J 2007, 13:17.
69. Nishie W: Update on the pathogenesis of bullous pemphigoid: an autoantibody-mediated blistering disease targeting collagen XVII. J Dermatol Sci 2014, 73:179-186.

70. Bastuji-Garin S, Joly P, Lemordant P, Sparsa A, Bedane C, Delaporte E, Roujeau J-C, Bernard P, Guillaume J-C, Ingen-Housz-Oro S, Maillard H, Pauwels C, Picard-Dahan C, Dutronc Y, Richard M-A, French Study Group for Bullous Diseases: Risk factors for bullous pemphigoid in the elderly: a prospective case-control study. J Invest Dermatol 2011, 131:637-643.

71. Lloyd-Lavery A, Chi C-C, Wojnarowska F, Taghipour K: The associations between bullous pemphigoid and drug use: a UK case-control study. JAMA Dermatol 2013, 149:58-62.

72. Kneisel A, Hertl M: Autoimmune bullous skin diseases. Part 2: diagnosis and therapy. J Dtsch Dermatol Ges 2011, 9:927-947.

73. Busse WW, Morgan WJ, Gergen PJ, Mitchell HE, Gern JE, Liu AH, Gruchalla RS, Kattan M, Teach SJ, Pongracic JA, Chmiel JF, Steinbach SF, Calatroni A, Togias A, Thompson KM, Szefler SJ, Sorkness CA: Randomized trial of omalizumab (anti-lgE) for asthma in inner-city children. $N$ Engl J Med 2011, 364:1005-1015.

\section{Submit your next manuscript to BioMed Central and take full advantage of:}

- Convenient online submission

- Thorough peer review

- No space constraints or color figure charges

- Immediate publication on acceptance

- Inclusion in PubMed, CAS, Scopus and Google Scholar

- Research which is freely available for redistribution

Submit your manuscript at www.biomedcentral.com/submit
C) BioMed Central 